\title{
Originals
}

\section{The biochemical basis of increased hepatic glucose production in a mouse model of type 2 (non-insulin-dependent) diabetes mellitus}

\author{
S. Andrikopoulos, J. Proietto \\ University of Melbourne, Department of Medicine, Royal Melbourne Hospital, Parkville, Victoria, Australia
}

Summary The mechanism of increased hepatic glucose production in obese non-insulin-dependent diabetic (NIDDM) patients is unknown. The New Zealand Obese (NZO) mouse, a polygenic model of obesity and NIDDM shows increased hepatic glucose production. To determine the mechanism of this phenomenon, we measured gluconeogenesis from $\mathrm{U}^{14} \mathrm{C}-$ glycerol and $\mathrm{U}^{14} \mathrm{C}$-alanine and relevant gluconeogenic enzymes. Gluconeogenesis from glycerol $\left(0.07 \pm 0.01\right.$ vs $0.21 \pm 0.02 \mu \mathrm{mol} \cdot \mathrm{min}^{-1} \cdot$ body mass in$\left.\operatorname{dex}(\mathrm{BMI})^{-1}, p<0.005\right)$ and alanine $(0.57 \pm 0.07 \mathrm{vs}$ $\left.0.99 \pm 0.07 \mu \mathrm{mol} \cdot \mathrm{min}^{-1} \cdot \mathrm{BMI}^{-1}, p<0.005\right)$ was elevated in control mice NZO vs as was glycerol turnover $\left(0.25 \pm 0.02\right.$ vs $0.63 \pm 0.09 \mu \mathrm{mol} \cdot \mathrm{min}^{-1} \cdot \mathrm{BMI}^{-1}$, $p<0.05)$. Fructose 1,6-bisphosphatase activity $\left(44.2 \pm 1.9\right.$ vs $55.7 \pm 4.1 \mathrm{nmol} \cdot \mathrm{min}^{-1} \cdot \mathrm{mg}$ protein $^{-1}$, $p<0.05)$ and protein levels $(6.9 \pm 1.1$ vs $16.7 \pm 2.3$ arbitrary units, $p<0.01$ ) were increased in NZO mouse livers, as was the activity of pyruvate carboxylase $\left(0.12 \pm 0.01\right.$ vs $0.17 \pm 0.02 \mathrm{nmol} \cdot \mathrm{min}^{-1} \cdot \mathrm{mg}$ protein ${ }^{-1}$, $p<0.05)$. To ascertain whether elevated lipid supply is responsible for these biochemical changes in NZO mice, we fed lean control mice a $60 \%$ fat diet for 2 weeks. Fat-fed mice were hyperinsulinaemic $(76.37 \pm 4.06$ vs $98.00 \pm 7.07 \mathrm{pmol} / \mathrm{l}, p=0.05)$ and had elevated plasma non-esterified fatty acid levels $(0.44 \pm 0.05$ vs $0.59 \pm 0.03 \mathrm{mmol} / 1, p=0.05)$. Fructose 1,6-bisphosphatase activity (43.86 \pm 2.54 vs $52.93 \pm 3.09 \mathrm{nmol} \cdot \mathrm{min}^{-1} \cdot \mathrm{mg}$ protein $\left.{ }^{-1}, p=0.05\right)$ and protein levels $(33.03 \pm 0.96$ vs $40.04 \pm 1.26$ arbitrary units, $p=0.005$ ) and pyruvate carboxylase activity $\left(0.10 \pm 0.003\right.$ vs $0.14 \pm 0.01 \mathrm{nmol} \cdot \mathrm{min}^{-1} \cdot \mathrm{mg}$ protein $\left.^{-1}, p<0.05\right)$ were elevated in fat-fed mice. We conclude that in NZO mice increased hepatic glucose production is due to elevated lipolysis resulting from obesity. [Diabetologia (1995) 38: 1389-1396]

Key words Gluconeogenesis, glycerol, alanine, fructose 1,6-bisphosphatase, pyruvate carboxylase.
Fasting hyperglycaemia is the characteristic feature of Type 2 non-insulin-dependent diabetes mellitus (NIDDM). A major contributing cause of fasting hyperglycaemia is an inappropriately high hepatic glu-

Received: 23 March 1995 and in revised form: 5 June 1995

Corresponding author: Professor J. Proietto, University of Melbourne, Department of Medicine, Royal Melbourne Hospital, Parkville Victoria 3050, Australia

Abbreviations: HGP, Hepatic glucose production; NZO, New Zealand Obese; FBPase, fructose 1,6-bisphosphatase; PC, pyruvate carboxylase; PEPCK, phosphoenolpyruvate carboxykinase; BMI, body mass index; NIDDM, non-insulin-dependent diabetes mellitus; NZC, lean control mice; NEFA, non-esterified fatty acids. cose production (HGP) [1-5]. Although in the past HGP has been overestimated due to failure to adequately prime the glucose pool [6], there is no doubt that a hepatic defect is present, since even a normal HGP is abnormal in the presence of elevated glucose and insulin. In NIDDM patients, an increase in the rate of gluconeogenesis has been reported [7-9], although the mechanism for this increase is not known. A possible explanation for hepatic insulin resistance is that it is part of a more widespread decrease in insulin action in NIDDM. As such, abnormalities in hepatic insulin receptor level and function have been sought in a variety of animal models of Type 2 diabetes (NIDDM) [10-12]. On the other hand, it has also been shown that hepatic insulin resis- 
tance can be produced by acute elevation of nonesterified fatty acids (NEFA) [13-15]. Excess lipid levels have been shown to stimulate gluconeogenesis, but the enzymatic mechanism responsible is not fully understood [16]. Moreover, previous studies have also reported alterations in hepatic insulin receptor binding and function in response to high-fat feeding [17] and secondary to exposure of hepatocytes to NEFA in vitro [18].

More recently it has been shown that there is an increased rate of glycerol conversion to glucose in obese NIDDM patients [19, 20]. Nurjhan et al. [19] have demonstrated that this is partly due to an increase in substrate supply and partly to an increase in the rate of intrahepatic conversion, and have postulated that the enzyme fructose 1,6-bisphosphatase (FBPase) could be the cause.

The New Zealand Obese (NZO) mouse is a polygenic model of obese Type 2 diabetes (NIDDM), characterised by genetically determined obesity as well as by fasting hyperglycaemia and hyperinsulinaemia. We have previously shown that the NZO mouse has increased HGP from an early age [21]. More recently we reported abnormal regulation of FBPase, while two other regulated gluconeogenic enzymes, phosphoenolpyruvate carboxykinase (PEPCK) and glucose 6-phosphatase, are appropriately reduced by the prevailing hyperglycaemia and hyperinsulinaemia present in this obese animal [22].

The aim of the present study was to measure gluconeogenesis from substrates entering the pathway at different levels in NZO and lean control (NZC) mice and to further investigate the mechanism for the abnormal regulation of FBPase in NZO mice. We report here that in NZO mice, gluconeogenesis is increased from both glycerol and alanine and that this is due to an increase in FBPase activity and protein levels and to an increase in pyruvate carboxylase (PC) activity, both of which are secondary to increased lipid availability.

\section{Materials and methods}

Materials. All chemicals were of analytical grade and were purchased from Sigma Chemical Company (St. Louis, Mo., USA). All enzymes were purchased from Boehringer Mannheim (Munich, Germany). U- ${ }^{14} \mathrm{C}$-glycerol, U- ${ }^{14} \mathrm{C}$-alanine and $6-{ }^{3} \mathrm{H}$ glucose were purchased from DuPont-NEN Research Products (North Sydney, NSW, Australia). Ion exchange resins were purchased from Bio-Rad Laboratories Pty Ltd (North Ryde, NSW, Australia).

\section{Gluconeogenesis studies}

Animals. NZO and NZC mice (19-20 weeks old) were purchased from the Walter and Eliza Hall Institute (Parkville, Victoria, Australia). Mice were fed ad libitum with a standard laboratory chow. Food was removed at approximately 15.00 hours and the mice were studied the following morning (09.00-10.00 hours). Mice were anaesthetised with an intraperitoneal injection of pentobarbitone sodium (Nembutal; Ceva Chemicals, NSW, Australia). Two catheters were inserted, one in the jugular vein for infusion of the tracers and one in the carotid artery for blood sampling. A tracheostomy was also performed to prevent upper respiratory tract obstruction. All experiments were approved by the Royal Melbourne Hospital animal ethics committee.

Experimental design. The experimental design for the measurement of gluconeogenesis from glycerol and alanine was essentially as described by Terrettaz and Jeanrenaud [23]. Briefly, two groups of mice were studied. In the first group, a bolus of $\mathrm{U}^{14} \mathrm{C}$-glycerol $(4.7 \mu \mathrm{Ci})$ and $6{ }^{3} \mathrm{H}$-glucose $(3.4 \mu \mathrm{Ci})$ was administered over $2 \mathrm{~min}$ and was immediately followed by a constant infusion of the same tracers at $0.2 \mu \mathrm{Ci} / \mathrm{min}$ for $\mathrm{U}-{ }^{14} \mathrm{C}$-glycerol and $0.14 \mu \mathrm{Ci} / \mathrm{min}$ for $6-{ }^{3} \mathrm{H}$-glucose for $2 \mathrm{~h}$. Blood was collected at 90,105 and 120 min after the bolus. At the end of the $2-h$ period a laparotomy was rapidly performed, the liver was freeze-clamped in situ with aluminium tongs pre-cooled in liquid nitrogen and stored at $-70^{\circ} \mathrm{C}$. In the second group of animals, $\mathrm{U}^{14} \mathrm{C}$-alanine replaced the glycerol tracer and the experimental procedure described above was followed.

Analytical procedures. For the determination of radioactivity in various metabolites derived from the infused tracers, $100 \mu \mathrm{l}$ of blood was deproteinised with $500 \mu \mathrm{l} 0.3 \mathrm{~mol} / \mathrm{B} \mathrm{Ba}(\mathrm{OH})_{2}$ and $500 \mu \mathrm{l} 0.3 \mathrm{~mol} / 1 \mathrm{ZnSO}_{4}$. After centrifugation the clear supernatant was decanted and stored at $-20^{\circ} \mathrm{C}$ until assayed.

Four hundred microlitres of the deproteinised blood was passed down three stacked columns. The first column contained $1.7 \mathrm{ml}$ of Dowex AG-50W-X8 $\left(\mathrm{H}^{+}, 100-200 \mathrm{mesh}\right)$ and amino acids were eluted with $4 \mathrm{ml}$ of $2 \mathrm{~mol} / 1 \mathrm{NH}_{4} \mathrm{Cl}$. The eluant was further treated as described by Golden et al. [24] to recover alanine. The second column contained $1.7 \mathrm{ml} \mathrm{AG-}$ 1-X8 ( $\mathrm{Cl}^{-}$form, $\left.100-200 \mathrm{mesh}\right)$ and lactate was eluted with $4 \mathrm{ml}$ of $0.1 \mathrm{~mol} / \mathrm{l} \mathrm{HCl}$. The third column contained $1.7 \mathrm{ml} \mathrm{AG}$ 1-X8 (borate form, 100-200 mesh) resin and glycerol was eluted first with $5 \mathrm{ml}$ of $20 \mathrm{mmol} / \mathrm{l}$ sodium tetraborate and then glucose was eluted with $4 \mathrm{ml}$ of $0.5 \mathrm{~mol} / 1$ acetic acid. The eluants were dried in a fan-forced oven, resuspended in $300 \mu l$ water, and $100 \mu \mathrm{l}$ was taken to measure total glucose, and glycerol or alanine concentrations. Scintillant $(3 \mathrm{ml}$; Readyvalue, Beckman, Palo Alto, Calif., USA) was added to the remaining $200 \mu \mathrm{l}$, and radioactivity was counted in a Beckman LS 3081 scintillation counter (Beckman Instruments Pty Ltd Victoria, Australia) using a dual-label program.

High-fat feeding studies. Lean control (NZC) mice were left on standard laboratory chow or were put on a high-fat diet ad libitum, with water available at all times. The high-fat diet consisted of $60 \%$ fat (safflower oil), $20 \%$ carbohydrate and $20 \%$ protein as well as a vitamin and mineral mixture. The mice were fed for 12 days, after which time they were fasted overnight. The next morning the mice were anaesthetised with an intraperitoneal injection of pentobarbitone sodium $(60 \mathrm{~g} / \mathrm{kg})$. After a $15-\mathrm{min}$ rest, a tail vein blood sample was taken in sequestrene tubes. Thirty minutes after the anaesthesia was induced, a laparotomy was rapidly performed and the liver was freeze-clamped in situ using aluminium tongs pre-cooled in liquid nitrogen. Livers were stored at $-70^{\circ} \mathrm{C}$ until assayed.

Enzyme assays. PC activity was measured according to the method of Brendt et al. [25]. Briefly, livers were homogenised $(1: 5 \mathrm{w} / \mathrm{v})$ in a medium containing $50 \mathrm{mmol} / 1$ Tris-acetate $(\mathrm{pH}$ 
6.5), $5 \mathrm{mmol} / 1 \mathrm{MgSO}_{4}, 5 \mathrm{mmol} / 1$ EDTA. The crude homogenate was sonicated in an ice-bath for $4 \times 30 \mathrm{~s}$ at 30 -s intervals. It was then centrifuged at $40,000 \mathrm{~g}$ for $50 \mathrm{~min}\left(2^{\circ} \mathrm{C}\right)$. The supernatant was decanted and used in the assay. The assay medium contained: (in mmol/l) 166 Tris- $\mathrm{HCl}$ ( $\mathrm{pH} \mathrm{8.0),} 1.7 \mathrm{ATP}, 8.3$ $\mathrm{MgCl}_{2}, 25 \mathrm{KHCO}_{3}, 8.3$ acetylphosphate, 0.83 coenzyme A (reduced form) (ASH), 3.3 units citrate synthase, 16.7 units phosphotransacetylase and either $2 \mathrm{mmol} / \mathrm{l}$ pyruvate (maximal activity) or $0.5 \mathrm{mmol} / \mathrm{l}$ pyruvate (submaximal activity) in a total volume of $0.6 \mathrm{ml}$. This was preincubated for $3 \mathrm{~min}$ at $37^{\circ} \mathrm{C}$ and the reaction started with the addition of the sample. The reaction was stopped after $20 \mathrm{~min}(10 \mathrm{~min}$ when assaying for submaximal activity) with $10-15 \mathrm{mg} \mathrm{KBH}_{4}$ containing traces of antifoam. The solution was acidified with $15 \% \mathrm{v} / \mathrm{v} \mathrm{HClO}_{4}$, neutralised with $2.5 \mathrm{~mol} / 1 \mathrm{KHCO}_{3}$ and brought to a final volume of $1 \mathrm{ml}$ with distilled water. The solution was left on ice for $20 \mathrm{~min}$ to precipitate proteins, then centrifuged at 2,000 $\mathrm{g}$ for $10 \mathrm{~min}$ and the citrate concentration was determined on the clear supernatant, according to the method of Dagley [26]. Enzyme activity is expressed as nmol citrate produced. min $^{-1} \cdot$ mg protein $^{-1}$.

The activity of FBPase at maximal substrate concentrations was measured as described by Pontremoli et al. [27] in livers from overnight-fasted NZO and NZC mice and from highand low-fat-fed NZC mice.

Western blotting. Tissue extracts were prepared as described for the enzyme assay. Western blotting was performed on $10 \%$ polyacrylamide gels loaded with $5 \mu \mathrm{g}$ of protein. Gels were transferred to nitrocellulose membrane and FBPase was detected using a rabbit anti-(mouse liver FBPase) serum (1:2000) which was a kind gift from Dr. H. Mizunuma (Akita University, Akita, Japan). The bands were localised on the nitrocellulose membrane using anti-rabbit antibody conjugated to horse-radish peroxidase (1:2500) (Dako Corporation, Carpinteria, Calif., USA) and were visualised by the enhanced chemiluminescence method (Amersham, Sydney, Australia). The bands were quantitated using a scanning densitometer (Molecular Dynamics, Victoria, Australia).

Other analytical procedures. Glucose in deproteinised samples [28], glycerol [29], alanine [30], glycogen [31] and glycerol 3phosphate [32] were measured using standard spectrophotometric methods with a Beckman DU-50 spectrophotometer (Beckman Instruments Pty Ltd).

Protein was determined in the supernatants assayed for enzyme activity with the use of a Bio-Rad microassay protein kit (Bio-Rad, Richmond, Calif., USA). The protein assay is based on the Coomassie Blue method using bovine serum albumin as the standard, read at an absorbance of $595 \mathrm{~nm}$.

NEFA levels were determined in plasma from blood collected in sequestrene tubes using an enzymatic colourimetric method supplied in a kit (Wako Pure Chemical Industries Ltd, Richmond, Va., USA).

Plasma glucose was measured using a Yellow Springs glucose analyser (Yellow Springs Instruments, Yellow Springs, Ohio, USA), which employs a glucose oxidase method. Plasma insulin was assayed by radioimmunoassay (Pharmacia Diagnostics, Uppsala, Sweden) using a double antibody technique to separate free from bound insulin.

Calculations. Rate of appearance ( $\mathrm{Ra}$ ) of glucose, glycerol and alanine was calculated by dividing the infusion rate of the tracer by its specific activity [33]. Rate of conversion of glycerol (and alanine) was calculated by multiplying the ${ }^{14} \mathrm{C}$-glucose specific activity with glucose $\mathrm{Ra} / 2$ and dividing by ${ }^{14} \mathrm{C}$-glycerol (or ${ }^{14} \mathrm{C}$-alanine) specific activity [23]. Pilot experiments were
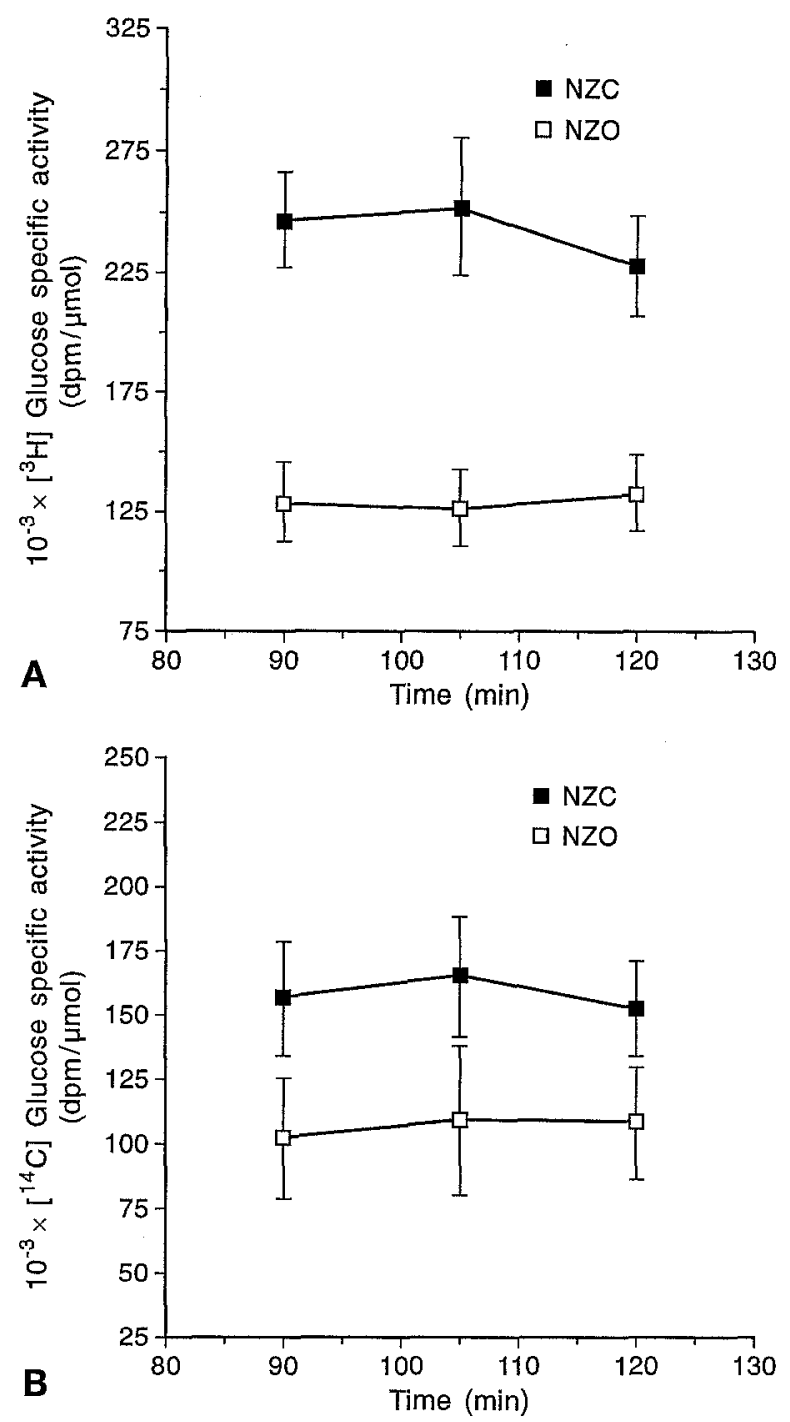

Fig. 1 A, B. Specific activities of ${ }^{3} \mathrm{H}$-glucose $(\mathbf{A})$ and ${ }^{14} \mathrm{C}$-glucose (B) in NZO and NZC mice at 90-120 min following the bolus showing steady-state $(n=8)$

performed to determine bolus to constant infusion ratios achieving steady-state conditions in the mice. Specific activity steady-state conditions were achieved within $90 \mathrm{~min}$ (Fig.1), allowing the use of the steady-state equation.

\section{Statistical analysis}

All results are expressed as mean \pm SEM. Statistical significance $(p<0.05)$ was determined by use of the Mann-Whitney non-parametric test.

\section{Results}

Characteristics of the animals used in the gluconeogenesis studies. Table 1 shows the age, body mass index (BMI), plasma glucose levels and insulin levels of the two groups of mice used in the measurement of gluconeogenesis from glycerol and alanine. In 
Table 1. Characteristics of animals used to measure gluconeogenesis from glycerol and alanine

\begin{tabular}{lllcc}
\hline & $\begin{array}{l}\text { Age } \\
\text { (weeks) }\end{array}$ & $\begin{array}{l}\text { BMI } \\
\left(\mathrm{g} / \mathrm{cm}^{2}\right)\end{array}$ & $\begin{array}{l}\text { Glucose } \\
(\mathrm{mmol} / \mathrm{l})\end{array}$ & $\begin{array}{l}\text { Insulin } \\
(\mathrm{pmol} / \mathrm{l})\end{array}$ \\
\hline $\begin{array}{llll}\text { Glycerol } \\
\text { NZC }\end{array}$ & $19.8 \pm 0.3$ & $0.30 \pm 0.01$ & $4.3 \pm 0.4$ & $93.0 \pm 12.7$ \\
NZO & $19.1 \pm 0.2$ & $0.42 \pm 0.02^{\mathrm{b}}$ & $8.3 \pm 0.4^{\mathrm{b}}$ & $272.2 \pm 40.0^{\mathrm{b}}$ \\
Alanine & & & & \\
NZC & $20.8 \pm 0.2$ & $0.29 \pm 0.01$ & $4.5 \pm 0.4$ & $44.2 \pm 3.3$ \\
NZO & $20.7 \pm 0.4$ & $0.44 \pm 0.01^{\mathrm{b}}$ & $11.1 \pm 2.4^{\mathrm{a}}$ & $252.9 \pm 39.0^{\mathrm{b}}$ \\
\hline
\end{tabular}

Values expressed as mean $\pm \operatorname{SEM}(n=7)$.

${ }^{\mathrm{a}} p<0.01 ;{ }^{\mathrm{b}} p<0.005$ compared to NZC mice

Table 2. Total HGP $\left(\mathrm{R}_{\mathrm{a} \text { (glucose) }}\right)$, rate of appearance of glycerol $\left(\mathrm{R}_{\mathrm{a}(\mathrm{glycerol})}\right)$ and glycerol conversion to glucose $\left(\mathrm{R}_{\text {glycerol }}\right)$

\begin{tabular}{llll} 
& $\begin{array}{l}\mathrm{Ra}(\text { glucose) } \\
\mu \mathrm{mol} \cdot \mathrm{min}^{-1}\end{array}$ & $\begin{array}{l}\mathrm{Ra}(\text { glycerol) } \\
\mu \mathrm{mol} \cdot \mathrm{min}^{-1}\end{array}$ & $\begin{array}{l}\text { Rglycerol } \\
\mu \mathrm{mol} \cdot \mathrm{min}^{-1}\end{array}$ \\
& $\mathrm{BMI}^{-1}$ & $\mathrm{BMI}^{-1}$ & $\mathrm{BMI}^{-1}$ \\
\hline $\mathrm{NZC}$ & $2.82 \pm 0.25$ & $0.25 \pm 0.02$ & $0.07 \pm 0.01$ \\
$\mathrm{NZO}$ & $4.08 \pm 0.27^{\mathrm{a}}$ & $0.63 \pm 0.09^{\mathrm{a}}$ & $0.21 \pm 0.02^{\mathrm{b}}$ \\
\hline
\end{tabular}

Values expressed as mean $\pm \operatorname{SEM}(n=7)$.

${ }^{\mathrm{a}} p<0.05 ;{ }^{\mathrm{b}} p<0.005$ compared to NZC mice

Table 3. Total HGP $\left(\mathrm{R}_{\text {a(glucose })}\right)$, rate of appearance of alanine $\left(\mathrm{Ra}_{(\text {alanine })}\right)$ and alanine conversion to glucose $\left(\mathrm{R}_{\text {alanine }}\right)$

\begin{tabular}{|c|c|c|c|}
\hline & $\begin{array}{l}\text { Ra(glucose }) \\
\mu \mathrm{mol} \cdot \min ^{-1} \\
\mathrm{BMI}^{-1}\end{array}$ & $\begin{array}{l}\text { Ra(alanine) } \\
\mu \mathrm{mol} \cdot \min ^{-1} \\
\mathrm{BMI}^{-1}\end{array}$ & $\begin{array}{l}\text { Ralanine } \\
\mu \mathrm{mol} \cdot \min ^{-1} \text {. } \\
\mathrm{BMI}^{-1}\end{array}$ \\
\hline NZC & $2.64 \pm 0.17$ & $6.72 \pm 1.22$ & $0.57 \pm 0.07$ \\
\hline $\mathrm{NZO}$ & $3.73 \pm 0.32^{\mathrm{a}}$ & $8.55 \pm 0.56$ & $0.99 \pm 0.07^{b}$ \\
\hline
\end{tabular}

Values expressed as mean $\pm \operatorname{SEM}(n=7)$.

${ }^{\mathrm{a}} p<0.01 ;^{\mathrm{b}} p<0.005$ compared to NZC mice

both cases the NZO mice had a higher BMI and were hyperglycaemic and hyperinsulinaemic compared to control NZC mice.

Gluconeogenesis from glycerol. Total HGP, rate of appearance of glycerol and gluconeogenesis from U${ }^{14} \mathrm{C}$-glycerol are shown in Table 2. Total HGP was higher in the NZO mice compared to the control mice as has been shown previously [21]. The rate of appearance of glycerol $\left(\mathrm{R}_{\mathrm{a}(\mathrm{glycerol})}\right)$ which is a measure of lipolysis, is also increased in NZO mice compared to controls and the rate of conversion of glycerol to glucose $\left(\mathrm{R}_{\text {giycerol }}\right)$ is approximately 3 times higher in the NZO mouse. Glycerol gluconeogenesis accounts for $2.5 \%$ of total HGP in NZC mice and $5.1 \%$ in NZO mice. The relationship between plasma glycerol and the rate of conversion of glycerol to glucose is shown in Figure 2. For the NZO mice which had a wide range of glycerol concentrations, there was a positive correlation $(r=0.81, p<0.05)$ between the two

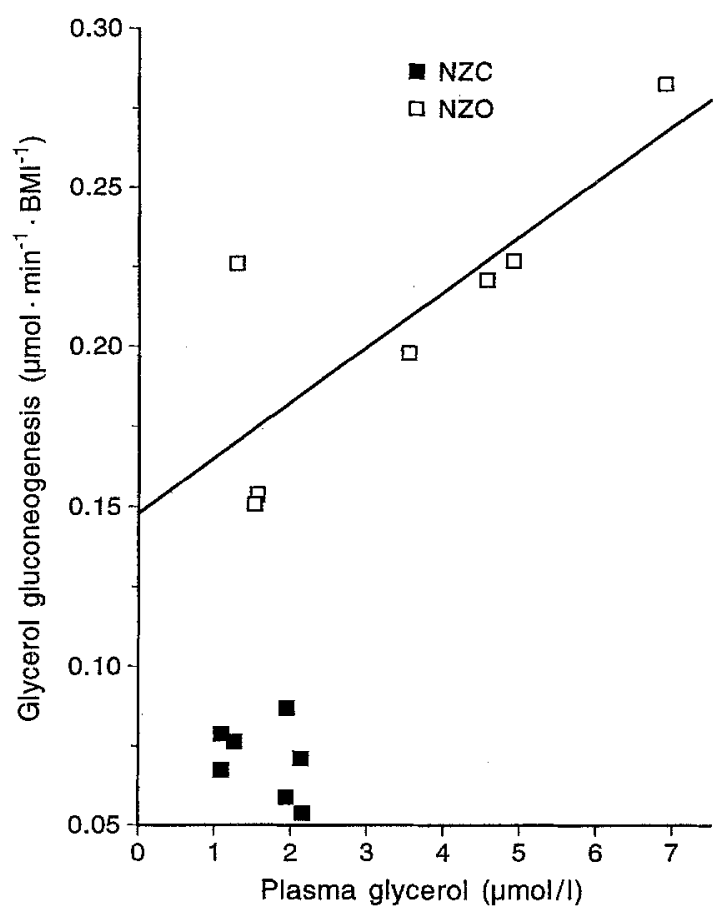

Fig. 2. Relationship between plasma glycerol concentrations and the rate of glycerol conversion to glucose in NZO and NZC mice $(n=7)$

parameters. As has been shown in human NIDDM [19], for the same glycerol concentrations, NZO mice converted more of this substrate to glucose than the control mice. This suggests an increase in the intrahepatic conversion of glycerol to glucose in the obese animals.

Gluconeogenesis from alanine. The results of gluconeogenesis from alanine are shown in Table 3. Again HGP was higher in the NZO mouse. Alanine conversion to glucose $\left(\mathrm{R}_{\text {alanine }}\right)$ was also increased in NZO mice compared to the NZC mice. Alanine gluconeogenesis accounts for $21.6 \%$ of total HGP in NZC mice and $26.5 \%$ in NZO mice. Despite this, plasma alanine concentrations $(12.4 \pm 2.4 \mathrm{vs} 13.9 \pm 1.3 \mu \mathrm{mol} / \mathrm{l}$ in NZC vs NZO mice, respectively) and the rate of appearance of alanine were not different in the two groups of mice. The relationship between plasma alanine levels and alanine gluconeogenesis is shown in Figure 3 . There was a positive correlation between these two parameters $(r=0.73, p<0.05)$ in the control mice since they had a wider range of alanine concentrations. However, for the same alanine concentration, the NZO mice had a higher conversion of this amino acid to glucose. This also suggests an increase in an intrahepatic mechanism.

FBPase activity and protein levels in overnight fasted $N Z O$ and $N Z C$ mice. To determine whether FBPase contributed to increased glycerol gluconeogenesis in NZO mice, activity at maximal substrate concentra- 


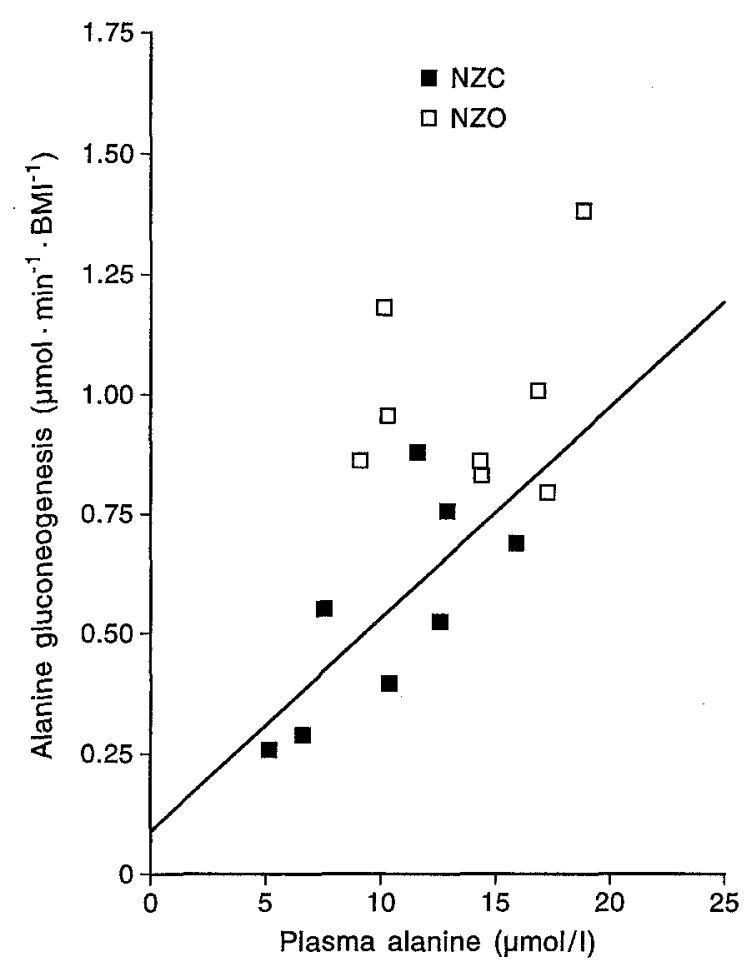

Fig. 3. Relationship between plasma alanine concentrations and the rate of alanine conversion to glucose in $\mathrm{NZO}$ and NZC mice $(n=8)$

tion and protein levels of this enzyme were measured in the livers from overnight fasted animals. The activity of FBPase was elevated in livers from NZO mice as compared to control NZC mice (Table 4). On Western blotting, the size of the band detected was 36,000 Daltons, which agrees well with the literature [34]. Protein levels were higher in NZO mice which was consistent with increased total activity.

Pyruvate carboxylase activity. To find a mechanism for the increased rate of alanine conversion to glucose in NZO mice, we measured the activity of PC, the enzyme which catalyses the first committed step of gluconeogenesis. PC activity at maximal and submaximal substrate concentrations was measured in the livers of animals in the alanine-tracer infusion studies and the results are presented in Table 5. There was no difference in the maximal enzyme activity, but NZO mice had a higher submaximal activity compared to controls.

Glycerol 3-phosphate, glycogen and NEFA levels in $N Z O$ and NZC mice. The levels of liver glycerol 3phosphate, glycogen and plasma NEFA are shown in Table 6. Glycerol 3-phosphate, glycogen and plasma NEFA were all significantly elevated in NZO mice compared to the NZC mice.

Characteristics of lean mice on control or high-fat diet. Age, fasting plasma glucose, insulin, and NEFA con-
Table 4. The activity and protein levels of FBPase in livers from fasted NZO and NZC mice

\begin{tabular}{lcc}
\hline & NZC mice & NZO mice \\
\hline $\begin{array}{l}\text { FBPase activity } \\
\left(\text { nmol } \cdot \min ^{-1} \cdot \text { mg protein }^{-1}\right)\end{array}$ & $44.21 \pm 1.88$ & $55.70 \pm 4.12^{\mathrm{a}}$ \\
$\begin{array}{l}\text { FBPase protein levels } \\
\text { (arbitrary units) }\end{array}$ & $6.95 \pm 1.07$ & $16.72 \pm 2.34^{\mathrm{b}}$ \\
\hline
\end{tabular}

Values are expressed as mean $\pm \operatorname{SEM}(n=8)$.

${ }^{\mathrm{a}} p=0.05 ;{ }^{\mathrm{b}} p=0.01$

Table 5. Maximal and sub-maximal (PC) enzyme activity in NZO and NZC mice used in the alanine infusion studies

\begin{tabular}{|c|c|c|}
\hline & $\begin{array}{l}\text { Maximal activity } \\
\mathrm{nmol} \cdot \mathrm{min}^{-1} \cdot \mathrm{mg} \text { protein }\end{array}$ & $\begin{array}{l}\text { Sub-maximal activity } \\
\mathrm{nmol} \cdot \mathrm{min}^{-1} \cdot \text { mg protein } \\
-1\end{array}$ \\
\hline $\mathrm{NZC}$ & $0.20 \pm 0.01$ & $0.12 \pm 0.01$ \\
\hline $\mathrm{NZO}$ & $0.22 \pm 0.02$ & $0.17 \pm 0.02^{a}$ \\
\hline
\end{tabular}

Values expressed as mean $\pm \operatorname{SEM}(n=7) .{ }^{\mathrm{a}} p<0.05$

Table 6. Liver glycerol 3-phosphate, glycogen and plasma NEFA in NZO and NZC mice

\begin{tabular}{llll}
\hline & $\begin{array}{l}\text { Glycerol 3-phosphate } \\
(\mu \mathrm{mol} / \mathrm{g} \text { liver })\end{array}$ & $\begin{array}{l}\text { Glycogen } \\
(\mu \mathrm{mol} / \mathrm{g} \text { liver })\end{array}$ & $\begin{array}{l}\mathrm{NEFA} \\
(\mathrm{mmol} / \mathrm{l})\end{array}$ \\
\hline NZC & $0.19 \pm \mathbf{0 . 0 2}$ & $11.63 \pm 2.13$ & $0.70 \pm 0.09$ \\
$\mathrm{NZO}$ & $0.29 \pm 0.03^{\mathrm{a}}$ & $25.97 \pm 3.26^{\mathrm{a}}$ & $1.02 \pm 0.10^{\mathrm{a}}$ \\
\hline
\end{tabular}

Values expressed as mean $\pm \operatorname{SEM}(n=7) .{ }^{\mathrm{a}} p<0.05$

Table 7. Characteristics of lean mice fed either a standard laboratory chow diet or a high-fat diet

\begin{tabular}{lcc}
\hline & Control diet & High-fat diet \\
\hline Age (weeks) & $20.07 \pm 0.43$ & $19.80 \pm 0.40$ \\
Glucose (mmol/1) & $7.50 \pm 0.52$ & $8.28 \pm 0.18$ \\
Insulin (pmol/1) & $76.37 \pm 4.06$ & $98.00 \pm 7.07^{\mathrm{a}}$ \\
NEFA (mmol/1) & $0.44 \pm 0.05$ & $0.59 \pm 0.03^{\mathrm{a}}$ \\
\hline
\end{tabular}

Values are expressed as mean $\pm \operatorname{SEM}(n=6) .{ }^{\mathrm{a}} p=0.05$

centrations of the NZC lean mice that were fed either a control diet or a high-fat diet are shown in Table 7. There was no difference in age between the two groups of mice, and there was no difference in plasma glucose concentration; however, plasma insulin and NEFA were higher in the high-fat-fed mice.

The change in weight between the two groups of mice during the 12-day period of the feeding study is shown in Figure 4. The high-fat-fed mice were significantly heavier than the control mice during the last 3 days of the study.

FBPase activity and protein levels and PC activity in lean mice fed a control or a high-fat diet. The activity of FBPase in livers of high-fat-fed mice was $20 \%$ higher than in control-fed mice (Table 8). To determine whether the high activity was due to an increased quantity of FBPase, the protein levels for 


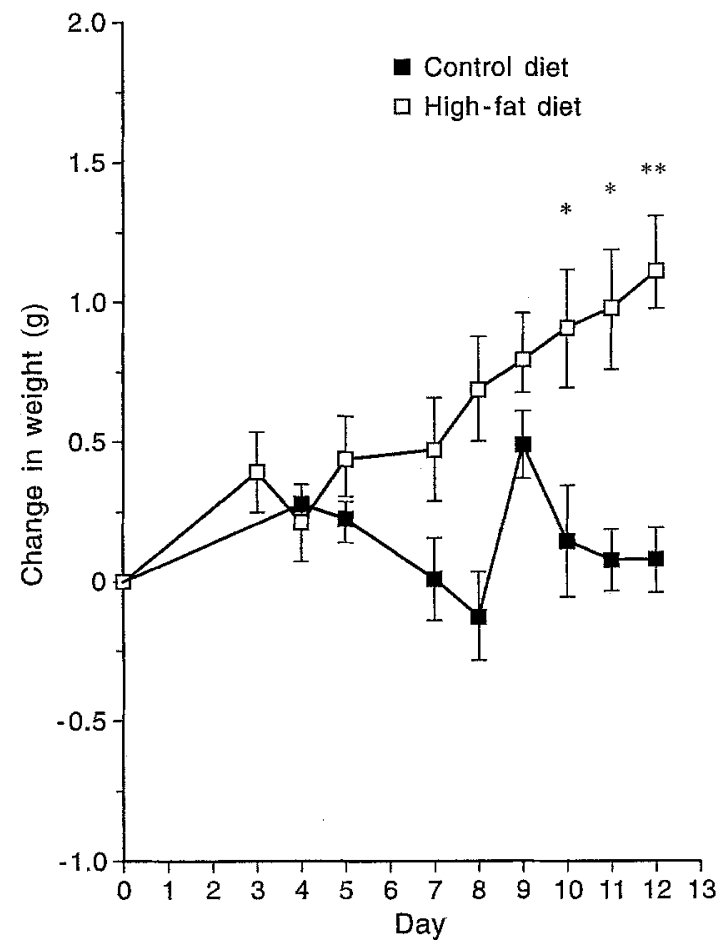

Fig.4. The change in weight in mice fed a high-fat diet or standard laboratory chow. The results were calculated as the difference in weight of each individual mouse from day 0 . Values are mean $\pm \mathrm{SEM}, n=6$. ${ }^{*} p<0.05 ; * * p<0.01$

Table 8. The activity and protein levels of FBPase and PC activity in livers from control and high-fat-fed mice

\begin{tabular}{lcc}
\hline & Control diet & High-fat diet \\
\hline $\begin{array}{l}\text { FBPase activity } \\
\left(\mathrm{nmol} \cdot \mathrm{min}^{-1} \cdot \mathrm{mg} \text { protein }\right.\end{array}$
\end{tabular}

Values are expressed as mean $\pm \operatorname{SEM}(n=6)$.

${ }^{\mathrm{a}} p=0.05 ;{ }^{\mathrm{b}} p=0.005$

this enzyme were determined. This correlated well with the activity for this enzyme, which was also $20 \%$ higher in the high-fat-fed mice (Table 8 ).

PC measured at submaximal substrate concentration was elevated in the high-fat-fed mice compared to the mice on the standard laboratory chow (Table 8).

\section{Discussion}

The NZO mouse, a polygenic model of Type 2 diabetes (NIDDM), has previously been shown to have increased HGP from an early age [21]. In the present study we report that this increased HGP is caused by increased gluconeogenesis from both glycerol, which enters the pathway at the triose phosphate step, and alanine, one of the many substrates entering at the start of the pathway. Elevated glycerol gluconeogenesis is shown to be due both to an increase in substrate supply, and to an increase in the rate of intracellular conversion to glucose, while elevated alanine gluconeogenesis is due to increased intracellular conversion with no increase in alanine availability. The increased rate of conversion to glucose is associated with increased activity of PC and increased activity and total protein levels of FBPase.

PC converts pyruvate to oxaloacetate in mitochondria and is thought to be the first committed step of the gluconeogenic pathway. It is not regulated by insulin $[35,36]$ but is allosterically activated by acetyl $\mathrm{CoA}$, the breakdown product of fatty acid metabolism [37, 38]. We found higher submaximal PC enzyme activity in NZO mice (Table 5) which could be the result of increased fatty acid oxidation. The higher NEFA levels measured in the NZO mouse (Table 6) could account for this finding [39]. The inappropriately high FBPase activity reported in this study confirms our previous findings [22] and we further show that the increased activity is due to higher protein levels. The mechanism for this increase in FBPase protein however was not clear.

Because changes in PC activity can be caused by high fatty acid oxidation, we postulated that the changes in FBPase could also be due to increased NEFA availability. To investigate this possibility, we fed lean control mice a $60 \%$ high-fat diet. This type of diet has been shown to cause hepatic insulin resistance in rats after only 3 days of feeding $[40,41]$. The high-fat diet caused an increase in weight gain compared to mice fed a control diet. There was no difference in plasma glucose levels, but the high-fat-fed mice had higher plasma insulin levels, indicating a state of insulin resistance. NEFA levels were also higher in fat-fed mice (Table 7). As expected, this diet resulted in an increased submaximal activity of PC consistent with allosteric activation. Interestingly, both maximal activity and protein levels of FBPase were also elevated suggesting that the observed changes in FBPase in the NZO mouse may also be due to increased NEFA availability. That increased fatty acid supply increases FBPase protein levels is a new finding and the mechanism is not clear. Both a decrease in protein degradation and an increase in protein synthesis are possible. We have preliminary data (not shown) that there is no increase in FBPasemRNA in NZO mouse livers, suggesting that the effect of NEFA is not on FBPase gene transcription.

These results, together with our previously published data on glycolytic and gluconeogenic enzymes in the NZO mouse [22], suggest that at least in this animal, hepatic insulin resistance may not be due to a defect in the insulin receptor or in its signalling 
pathway. Increases in the glycolytic enzymes glucokinase and pyruvate kinase and decreases in the gluconeogenic enzymes PEPCK and glucose 6-phosphatase, present in this animal [22], suggest a normal capacity of the liver to respond to insulin. This, combined with the fact that in the present study we show that fat-induced changes in the activity of FBPase and in PC can reproduce the hepatic enzyme defects in the NZO mouse suggest that the apparent hepatic insulin resistance in this animal is unrelated to the insulin effector pathway.

These findings suggest a mechanism for hepatic insulin resistance in NIDDM. Previous studies have shown that in NIDDM elevated NEFA levels are at least partly responsible for impaired suppression of HGP by insulin $[14,42,43]$. Furthermore, as with the NZO mouse, NIDDM patients have increased conversion of glycerol to glucose $[19,20]$. Nurjhan et al. [19] infused glycerol into control patients to match the levels seen in obese diabetic patients, and found that the control patients still had lower rates of glycerol conversion to glucose than the NIDDM patients. They postulated that in obese NIDDM patients there is an intrahepatic mechanism responsible for the increased conversion of glycerol to glucose and suggested that this could be an increase in the levels of fructose 1,6-bisphosphatase. In contrast to glycerol, Consoli et al. [44] have shown that although gluconeogenesis from alanine is increased, this is entirely due to an increase in the availability of alanine. Interestingly, however, they found evidence for an increased intracellular conversion of lactate to glucose. In the present study although there was no difference in alanine levels between the lean and obese animals, there was a trend for alanine turnover to be higher in the NZO mice (Table 3), suggesting that, as for glycerol, there may be some contribution of increased substrate availability to alanine gluconeogenesis. However, Figure 3 also shows that there is an increase in intracellular conversion of this amino acid to glucose. Considering all the facts, one can postulate that in obese NIDDM patients, elevated HGP is caused by increased fatty acid oxidation $[45,46]$.

It has been suggested that increased gluconeogenesis would not result in increased HGP since infusion of intralipid [47] or lactate [48] in healthy subjects has been shown to increase the rate of gluconeogenesis without increasing HGP. This has been interpreted as showing autoregulation of HGP by the liver. In the NZO mouse however, increased gluconeogenesis is associated with increased HGP. This does not necessarily indicate the failure of an autoregulatory mechanism. There is a major difference between infusing excess substrates in overnight-fasted normal individuals who have depleted glycogen stores, and increased gluconeogenesis in a situation where glycogen levels are not very low as shown to be the case in the NZO mouse (Table 6). One may speculate therefore, that increased gluconeogenesis initially repletes liver glycogen but if glycogen levels are high as a result of chronic elevated gluconeogenesis or soon after a meal, the excess glucose produced can be released into the circulation [49].

It is concluded that NZO mice have hepatic glucose overproduction due to an increased supply of glycerol and increased rate of glycerol and alanine conversion to glucose. The biochemical mechanisms responsible for these changes are increased activities of PC and activity and protein levels of FBPase both resulting from elevated NEFA levels.

Acknowledgements. We would like to thank Dr. G. Collier (Deakin University, Geelong, Victoria, Australia) for providing the high-fat diet and Ms. S. Fabris for excellent technical assistance. This work was supported by a program grant from the National Health and Medical Research Council of Australia and from a grant in aid from ApexDiabetes Australia Research and Education Grant.

\section{References}

1. DeFronzo RA, Simonson D, Ferrannini E (1982) Hepatic and peripheral insulin resistance: a common feature of type 2 (non-insulin-dependent) and type 1 (insulin dependent) diabetes mellitus. Diabetologia 23: 313-319

2. Best JD, Judzewitsch RG, Pfeiffer MA, Beard JC, Halter JB, Porte D (1982) The effect of chronic sulfonyl urea therapy on hepatic glucose production in non-insulin-dependent diabetes mellitus. Diabetes 31: 333-338

3. Campbell PJ, Mandarino LJ, Gerich JE (1988) Quantification of the relative impairment in actions of insulin on hepatic glucose production and peripheral glucose uptake in non-insulin-dependent diabetes mellitus. Metabolism 37: $15-21$

4. DeFronzo RA, Ferrannini E, Simonson D (1989) Fasting hyperglycemia in non-insulin-dependent diabetes mellitus: contributions of excessive hepatic glucose production and impaired glucose uptake. Metabolism 38: 387-395

5. Butler PC, Rizza RA (1991) Contribution to postprandial hyperglycemia and effect on initial splanchnic glucose clearance of hepatic glucose cycling in glucose-intolerant or NIDDM patients. Diabetes 40: 73-81

6. Hother-Nielsen O, Beck-Nielsen N (1990) On the determination of basal glucose production rate in type 2 (non-insulin-dependent) diabetes mellitus using primed-continuous ${ }^{3}{ }^{3} \mathrm{H}$ glucose infusion. Diabetologia 33: 603-610

7. Consoli A, Nurjhan N, Capani F, Gerich J (1989) Predominant role of gluconeogenesis in increased hepatic glucose production in NIDDM. Diabetes 38: 550-557

8. Mitrakou A, Kelley D, Veneman Tet al. (1990) Contribution of abnormal muscle and liver glucose metabolism to postprandial hyperglycemia in NIDDM. Diabetes 39: 1381-1390

9. Magnusson I, Rothman DL, Katz LD, Shulman RG, Shulman GI (1992) Increased rate of gluconeogenesis in type II diabetes mellitus. $\mathrm{A}{ }^{13} \mathrm{C}$ nuclear magnetic resonance study. J Clin Invest 90: 1323-1327

10. Amatruda JM, Roncone AM (1985) Normal hepatic insulin receptor autophosphorylation in nonketotic diabetes mellitus. Biochem Biophys Res Com 129: 163-170 
11. Bisbis S, Bailbe D, Tormo MA et al. (1993) Insulin resistance in the GK rat: decreased receptor number but normal kinase activity in the liver. Am J Physiol 265:E807-E813

12. Nadiv O, Shinitzky M, Manu M et al. (1994) Elevated protein tyrosine phosphatase activity and increased membrane viscosity are associated with impaired activation of the insulin receptor kinase in old rats. Biochem J 298: 443-450

13. Bevilacqua S, Bonadonna R, Buzzigoli G et al. (1987) Acute elevation of free fatty acid levels leads to hepatic insulin resistance in obese subjects. Metabolism 36: 502-506

14. Lee KU, Lee HK, Koh CS, Min HK (1988) Artificial induction of intravascular lipolysis by lipid-heparin infusion leads to insulin resistance in man. Diabetologia 31: 285-290

15. Saloranta C, Koivisto V, Widen E et al. (1993) Contribution of muscle and liver to glucose-fatty acid cycle. Am J Physiol 264:E599-E605

16. Williamson JR, Kreisberg RA, Felts PW (1966) Mechanism for the stimulation of gluconeogenesis by fatty acids in perfused rat liver. Proc Natl Acad Sci USA 56: 247-254

17. Watawari T, Kobayashi M, Takata Y, Sasaoka T, Iwasaki M, Shigeta Y (1988) Alteration of insulin-receptor kinase activity by high-fat feeding. Diabetes 37: 1397-1404

18. Svedberg J, Bjorntorp P, Smith U, Lonnroth P (1992) Effect of free fatty acids on insulin receptor binding and tyrosine kinase activity in hepatocytes isolated from lean and obese rats. Diabetes 41: 294-298

19. Nurjhan N, Consoli A, Gerich J (1992) Increased lipolysis and its consequences on gluconeogenesis in non-insulin-dependent diabetes mellitus. J Clin Invest 89: 169-175

20. Puhakainen I, Koivisto VA, Yki-Jarvinen H (1992) Lipolysis and gluconeogenesis from glycerol are increased in patients with noninsulin-dependent diabetes mellitus. J Clin Endocrinol Metab 75: 789-794

21. Veroni M, Proietto J, Larkins RG (1991) Evolution of insulin resistance in New Zealand Obese mice. Diabetes 40: $1480-1487$

22. Andrikopoulos S, Rosella G, Gaskin E et al. (1993) Impaired regulation of hepatic fructose-1,6-bisphosphatase in the New Zealand obese mouse model of NIDDM. Diabetes 42: 1731-1736

23. Terrettaz J, Jeanrenaud B (1990) Contribution of glycerol and alanine to basal hepatic glucose production in the genetically obese (fa/fa) rat. Biochem J 270: 803-807

24. Golden S, Chenoweth M, Dunn A, Okajima F, Katz J (1981) Metabolism of tritium- and ${ }^{14} \mathrm{C}$-labeled alanine in rats. Am J Physiol 241:E121-E128

25. Brendt J, Messner B, Turkki T, Weissmann E (1978) Optical assay of pyruvate carboxylase in crude liver homogenates. Anal Biochem 86: 154-158

26. Dagley S (1974) Citrate. In: Bergmeyer HU (ed) Methods of enzymatic analysis. Academic Press, New York, pp $1562-1569$

27. Pontremoli S, Traniello S, Luppis B, Wood WA (1965) Fructose diphosphatase from rabbit liver. J Biol Chem 240: 3459-3463

28. Kunst A, Draeger D, Ziegenhorh N (1974) D-Glucose. In: Bergmeyer HU (ed) Methods of enzymatic analysis. Academic Press, New York, pp 163-172

29. Eggstein M, Kuhlmann E (1974) Triglycerides and glycerol. In: Bergmeyer HU (ed) Methods of enzymatic analysis. Academic Press, New York, pp 1825-1831

30. Williamson DH (1974) L-Alanine. In: Bergmeyer HU (ed) Methods of enzymatic analysis. Academic Press, New York, pp 1679-1682

31. Keppler D, Decker K (1974) Glycogen. In: Bergmeyer HU (ed) Methods of enzymatic analysis. Academic Press, New York, pp 11-18
32. Michal G, Lang G (1974) L-(-)-Glycerol-3-phosphate. In: Bergmeyer HU (ed) Methods of enzymatic analysis. Academic Press, New York, pp 1415-1418

33. Steele R (1959) Influences of glucose loading and of injected insulin on hepatic glucose output. Ann NY Acad Sci 82: $420-430$

34. Tashima Y, Mizunuma H, Hasegawa M (1979) Purification and properties of mouse liver fructose 1,6-bisphosphatase. J Biochem 86: 1089-1099

35. Brech W, Shrago E, Wilken D (1970) Studies on pyruvate carboxylase in rat and human liver. Biochim Biophys Acta 201: 145-154

36. Peret J, Chanez M (1976) Influence of diet, cortisol and insulin on the activity of pyruvate carboxylase and phosphoenolpyruvate carboxykinase in the rat liver. J Nutr 106: 103-110

37. McClure WR, Lardy HA (1971) Rat liver pyruvate carboxylase IV. Factors affecting the regulation in vivo. $J$ Biol Chem 246: 3591-3596

38. Nakashima K, Rudolph FB, Wakabayashi T, Lardy HA (1975) Rat liver pyruvate carboxylase. V. Reversible dissociation by chloride salts of monovalent cations. J Biol Chem 250: 331-336

39. Walter P, Stucki JW (1970) Regulation of pyruvate carboxylase in rat liver mitochondria by adenine nucleotides and short chain fatty acids. Eur J Biochem 12: 508-519

40. Kraegen EW, Clark PW, Jenkins AB, Daley EA, Chisholm DJ, Storlien LH (1991) Development of muscle insulin resistance after liver insulin resistance in high-fat-fed rats. Diabetes 40: 1397-1403

41. Storlien LH, Jenkins AB, Chisholm DJ, Pascoe WS, Khouri S, Kraegen EW (1991) Influence of dietary fat composition on development of insulin resistance in rats. Relationship to muscle triglyceride and omega-3 fatty acids in muscle phospholipid. Diabetes 40: 280-289

42. Groop LC, Bonadonna RC, Del Prato S et al. (1989) Glucose and free fatty acid metabolism in non-insulin-dependent diabetes mellitus. J Clin Invest 84: 205-213

43. Walker M, Agius L, Orskov H, Alberti KGMM (1993) Peripheral and hepatic insulin sensitivity in non-insulin-dependent diabetes mellitus: effect of nonesterified fatty acids. Metabolism 42: 601-608

44. Consoli A, Nurjhan N, Reilly JJ Jr, Bier DM, Gerich J (1990) Mechanism of increased gluconeogenesis in noninsulin-dependent diabetes mellitus. Role of alterations in systemic, hepatic, and muscle lactate and alanine metabolism. J Clin Invest 86: 2038-2045

45. Foley JE (1992) Rationale and application of fatty acid oxidation inhibitors in treatment of diabetes mellitus. Diabetes Care 15: 773-781

46. Reaven GM (1995) The fourth musketeer - from Alexandre Dumas to Claude Bernard. Diabetologia 38: 3-13

47. Clore JN, Glickman PS, Nestler JE, Blackard WG (1991) In vivo evidence for hepatic autoregulation during FFA-stimulated gluconeogenesis in normal humans. Am J Physiol 261:E425-E429

48. Jenssen T, Nurjhan N, Consoli A, Gerich J (1990) Failure of substrate-induced gluconeogenesis to increase overall glucose appearance in normal humans. Demonstration of hepatic autoregulation without a change in plasma glucose concentration. J Clin Invest 86: 489-497

49. Kruszynska YT, McCormack JG, McIntyre N (1991) Effects of glycogen stores and non-esterified fatty acid availability in insulin-stimulated glucose metabolism and tissue pyruvate dehydrogenase activity in the rat. Diabetologia 34: 205-211 